\title{
KESANTUNAN IMPERATIF DALAM INTERAKSI ANTARMAHASISWA FAKULTAS TARBIYAH DAN ILMU KEGURUAN IAIN PONTIANAK: Kajian Pragmatik dan Etis Pendidikan Islam
}

\author{
Muchammad Djarot dan Marsih Muhammad \\ IAIN Pontianak, Indonesia \\ muhammad_djarot@yahoo.com
}

\begin{abstract}
Imperative politeness is one of focus in character building education. This is because language politeness or in spoken language is part of main pilars in character education. Based on the research, students of teacher training and education faculty in State Islamic Institute Pontianak showed the students tend less polite in spoken. This reveals from their imperative spoken in interaction among them. Meanwhile their spoken language that they used represents their characteristics and become problematic because they are studying at teacher training and education faculty in State Islamic Institute Pontianak in which is place for graduating candidate of teachers. In methodology, this research is qualitative with pragmatic approach. In the research, method of collecting data used method of listening and capability. Object of the research is students who study at teacher training and education faculty in State Islamic Institute Pontianak.
\end{abstract}

Keywords: Imperative Politeness and Students.

Abstrak: Kesantunan imperatif merupakan salah satu yang menjadi perhatian dalam pendidikan karakter. Hal ini karena kesantunan berbahasa atau bertutur menjadi bagian dari pilar pendidikan karakter. Berdasarkan hasil penelitian, mahasiswa Fakultas Tarbiyah dan Ilmu Keguruan Institut Agama Islam Negeri (IAIN) Pontianak menunjukkan kecenderungan kurang santun dalam bertutur, hal ini nampak dari tuturan imperatif yang mereka sampaikan dalam interaksi antarmereka. Sementara bahasa tutur yang mereka gunakan mewakili kepribadian mereka, dan menjadi problematik karena mereka sedang studi di Fakultas Tarbiyah dan Ilmu Keguruan IAIN Pontianak yang memang disiapkan menjadi calon-calon guru. Secara metodologis, penelitian ini tergolong penelitian kualitatif dengan pendekatan pragmatik. Dalam penelitian, metode pengumpulan data yang digunakan adalah metode simak dan metode cakap. Sementara objek kajiannya adalah mahasiswa yang studi di Fakultas Tarbiyah dan Ilmu Keguruan IAIN Pontianak.

Kata Kunci: Kesantunan Imperatif dan Mahasiswa.

\section{A. Pendahuluan}

Kesantunan imperatif merupakan salah satu yang menjadi perhatian dalam pendidikan karakter. Hal ini karena kesantunan berbahasa atau bertuturmenjadi bagian dari pilar pendidikan karakter. Hal ini sejalan dengan amanah pendidikan nasional yang berfungsi untuk mengembangkan kemampuan dan serta membentuk 
karakter peradaban bangsa yang bermartabat dalam rangka mencerdaskan kehidupan bangsa. Dalam hal ini pendidikan nasional bertujuan pada perkembangan potensi peserta didik sehingga beriman dan bertaqwa pada Tuhan YME, berakhlaqul karimah, sehat, berilmu, cakap, kreatif, mandiri, serta menjadi warga negara yang bertanggung jawab dan demokratis. ${ }^{180}$

Kesantunan imperatif ini seringkali luput dari perhatian institusi pendidikan dalam membangun karakter, termasuk institusi pendidikan Islam pada semua level atau jenjangnya. Termasuk pada Perguruan Tinggi Keagamaan Islam (PTKI). Keberhasilan pendidikan semata diukur dari aspek intelektualitas dengan sedikit mengabaikan aspek pembinaan karakter. Pantas saja, sering dijumpai tuturantuturan mahasiswa yang kurang santun ${ }^{181}$.

Fokus artikel ini adalah tentang kesantunan imperatif antarmahasiswa di Fakultas Tarbiyah dan Ilmu Keguruan Institut Agama Islam Negeri (IAIN) Pontianak. Fokus ini selanjutnya dijabarkan, pada beberapa pertanyaan, yaitu bagaimana wujud kesantunan imperatif antarmahasiswa di Fakultas Tarbiyah dan Ilmu Keguruan (FTIK) Institut Agama Islam Negeri IAIN Pontianak? Bagaimana pula makna dasar pragmatik imperatif dalam interaksi antar mahasiswa di FTIK IAIN Pontianak ditinjau dari tingkat ilmu dan status kelembagaan? Bagaimana kesantunan imperatif antarmahasiswa di FTIK IAIN Pontianak jika ditinjau dari aspek etis pendidikan Islam?

Alasan dipilihnya FTIK IAIN Pontianak ialah mengingat pada fakultas ini yang memang mahasiswanya disiapkan menjadi calon-calon guru. Di FTIK IAIN Pontianak terdapat empat Program Studi saat ini di FTIK IAIN Pontianak, yaitu Pendidikan Agama Islam (PAI), Pendidikan Bahasa Arab (PBA), Pendidikan Guru Madrasah Ibtidaiyah (PGMI) dan Pendidikan Islam Anak Usia Dini (PIAUD). Apalagi, berdasarkan wawancara dengan sejumlah pimpinan fakultas dan jurusan di di IAIN Pontianak pada beberapa kesempatan diperoleh simpulan bahwa belum ada aturan yang tertuang dalam kode etik mahasiswa yang mengatur tentang ini di IAIN Pontianak. Etika mahasiswa dalam kode etik mahasiswa masih dijabarkan dalam

180 Undang-Undang Republik Indonesia Nomor 20 Tahun 2003 tentang Sistem Pendidikan 181 Sofyan Sauri, Meretas Pendidikan Nilai, (Ed. 1), (Bandung: Arfino Raya, 2010), hlm. 2. 
penjelasannya yang umum, dan tidak mengatur tentang kesantunan bertutur atau berbahasa.

Apalagi, mahasiswa di FTIK IAIN Pontianak sebagai masyarakat kampus menyadari keberadaannya sebagai bagian tipologi komunitas masyarakat hard shelled, di mana pada komunitas ini terjadi interaksi minimal dan pemeliharaan maksimal pada Bahasa dan budaya. Pada aras ini, mahasiswa sudah sepatutnya menjaga keselarasan hubungan dengan sebisa mungkin dilandasi oleh kesantunan berbahasa. Sebab itu, kesantunan dalam bertutur, termasuk dalam mengungkapkan perintah, keharusan atau melarang temannya dilakukan secara santun. Terjadinya kesenjangan antara kenyataan dan harapan ini, menjadi latar belakang ketertarikan peneliti pada objek kajian ini.

Kontribusi artikel ini secara teoritis ada dua. Pertama, memberikan sumbangsih untuk perkembangan teori-teori pragmatik, juga untuk membantu penelitian-penelitian berikutnya yang berhubungan dengan kesantunan berbahasa, khususnya kajian tentang kesantunan imperative. Kedua, memberikan deskripsi teoritis tentang wujud pemakaian kesantunan imperatif dan makna dasar pragmatik dalam kesantunan imperatif pada interaksi antar mahasiswa.

Sementara secara praktis ada tiga. Pertama, memberikan masukan tentang pentingnya mekanisme yang mengatur tentang kesantunan berbahasa antar mahasiswa di IAIN Pontianak, khususnya di Fakultas Tarbiyah dan Ilmu Keguruan. Kedua, menjadi dasar pertimbangan dalam penyusunan buku kode etik mahasiswa di IAIN Pontianak, yang selanjutnya acuan dalam penyusunan buku kode etik mahasiswa di Fakultas Tarbiyah dan Ilmu Keguruan. Ketiga, menjadi masukan bagi dosen pengampu mata kuliah etika profesi guru, pendidikan karakter, maupun bahasa Indonesia di Fakultas Tarbiyah dan Ilmu Keguruan IAIN Pontianak, untuk memberikan porsi pembahasan tentang kesantunan imperatif.

Sejauh literature review yang peneliti lakukan, belum banyak penelitian yang secara spesifik membahas kesantunan imperatif dalam interaksi antarmahasiswa. Penelitian tentang kesantunan imperatif telah dilakukan sejumlah peneliti, namun tidak sama objek kajian dan perspektif kajian yang digunakan dengan fokus artikel 
ini. Yeti Prastika Adelina melakukan penelitian dengan judul, Kesantunan Imperatif dalam Wacana Pertemuan Kedinasan PCNA Sukolilo Kabupaten Pati.

Hasil penelitian ini menyimpulkan bahwa wujud imperatif dalam wacana kedinasan PCNA Sukolilo mempunyai dua bentuk yakni wujud formal dan wujud pragmatik imperatif. Secara formal, wujud imperatif dalam wacana kedinasan PCNA Sukolilo ditemukan beberapa perwujudan, yakni: pertama, imperatif aktif transitif; kedua, imperatif aktif tidak transitif; dan ketiga, imperatif pasif. Penggunaan wujud kesantunan dalam wacana kedinasan PCNA Sukolilo ditandai oleh beberapa hal, yang meliputi: panjang pendek tuturan, urutan tuturan, intonasi dan isyarat-isyarat kinesik, dan ungkapan-ungkapan penanda kesantunan. Ungkapan-ungkapan penanda kesantunannya menggunakan penanda kesantunan mari (marilah), mohon, silakan, tolong, dan jangan. Selain itu juga menggunakan kata bayangkan, berikan, manfaatkan, dan ambilkan.

Peringkat kesantunan direktif berdasarkan strategi kesantunan terdiri dari lima strategi. Pertama, strategi langsung tanpa basa-basi terdapat 21 tuturan. Kedua, kesantunan positif terdapat 58 tuturan. Ketiga, kesantunan negatif terdapat 13 tuturan. Keempat, tidak langsung terdapat 11 tuturan. Kelima, tindak pengancaman muka terdapat lima tuturan. ${ }^{182}$

Beberapa penelitian di atas berbeda dengan fokus artikel ini, yang membahas tentang kesantunan imperatif dalam interaksi antarmahasiswa Melayu Sambas di FTIK IAIN Pontianak, atau secara khusus ingin memotret wujud kesantunan imperatif antar mahasiswa Melayu Sambas di FTIK IAIN Pontianak serta mendalami makna dasar pragmatik imperatif dalam interaksi antarmahasiswadi FTIK IAIN Pontianak ditinjau dari tingkat ilmu dan status kelembagaan. Secara metodologis, penelitian ini tergolong penelitian kualitatif dengan pendekatan pragmatik. Dalam penelitian, metode pengumpulan data yang digunakan adalah metode simak dan metode cakap.

182 Yeti Prastika Adelina, "Kesantunan Imperatif dalam Wacana Pertemuan Kedinasan PCNA Sukolilo Kabupaten Pati," Skripsi tidak diterbitkan, Universitas Muhammadiyah Surakarta, 2013, hlm. 13. 


\section{B. Kajian Kesantunan Imperatif dalam Tuturan}

Kesantunan di dalam tuturan imperatif sangat penting dilakukan oleh penutur untuk menghargai mitra tutur. Secara linguistik, kesantunan dalam pemakaian tuturan imperatif sangat ditentukan oleh muncul atau tidak munculnya ungkapan-ungkapan penanda kesantunan. Untuk menilai santun tidaknya sebuah tuturan dapat digunakan skala ketidaklangsungan. Skala ketidaklangsungan menunjuk kepada peringkat langsung atau tidaknya sebuah tuturan. Semakin suatu tuturan bersifat langsung, maka semakin dianggap tidak santunlah tuturan itu dan semakin suatu tuturan bersifat tidak langsung maka semakin dianggap santunlah tuturan itu. Kesantunan dalam tuturan imperatif sangat ditentukan oleh muncul tidaknya ungkapan-ungkapan penanda kesantunan seperti maaf, tolong, coba, mohon, dan sebagainya.

Adapun kadar relasi atau hubungan antara tuturan imperatif dengan tindaktindak tutur itu adalah sebagai berikut: pertama, sebagai tindak lokusi tuturan imperatif merupakan pernyataan makna dasar dari konstruksi imperatif; kedua, sebagai tindak ilokusi makna imperatif yang pada dasarnya merupakan maksud yang disampaikan penutur dalam menyampaian tuturan imperatif, dan ketiga, sebagai tindak perlokusi sosok imperatif yang berkaitan dengan dampak yang timbul sebagai akibat dari tindak tutur. ${ }^{183}$

Kesantunan imperatif dalam tuturan yaitu mengandung maksud memerintah atau meminta agar mitra tutur melakukan sesuatu sebagaimana diinginkan oleh penutur yaitu dengan menerapkan prinsip kesantunan sebagai refleksi dari tindak kesantunan berbahasa. Kesantunan linguistik tuturan imperatif mencakup panjang pendek tuturan, urutan tutur, intonasi tuturan dan isyarat-isyarat kinesik, serta pemakaian ungkapan penanda kesantunan. ${ }^{184}$

Pertama, panjang pendek tuturan. Panjang pendek tuturan yang digunakan dalam bertutur, erat kaitannya dengan masalah kesantunan. Orang yang bertutur secara langsung dalam menyampaikan maksud tuturnya maka akan dianggap

183 Kunjana Rahardi, Pragmatik: Kesantunan Imperatif Bahasa Indonesia, (Jakarta: Erlangga, 2005) hlm. 67.

184 Ibid., hlm. 118. 
sebagai orang yang tidak sopan. Semakin panjang tuturan yaitu dengan menggunakan unsur basa-basi dalam kegiatan bertutur, maka orang tersebut akan dikatakan sebagai orang yang santun. Semakin panjang tuturan seseorang semakin besar pula keinginan orang itu untuk bersikap santun kepada mitra tutur atau lawan bicaranya. Contoh tuturan: (a) Tas merah itu!; (b) Ambil tas merah itu! (c) Ambilkan tas merah itu!; (d) Tolong ambilkan tas merah itu!. Dari contoh tuturan tersebut dapat dikatakan bahwa tuturan yang memiliki jumlah kata banyak atau tuturannya panjang maka tuturan itulah yang dianggap santun.

Kedua, urutan tutur. Pada kegiatan bertutur urutan tutur juga erat kaitannya dengan kesantunan tuturan. Untuk mengutarakan maksud tertentu, biasanya orang akan mengatur urutan tuturnya agar menjadi tuturan yang tegas, kasar maupun sopan. Maka tuturan imperatif yang diawali dengan informasi nonimperatif di depannya akan memiliki nilai kesantunan yang lebih tinggi daripada tuturan imperatif yang tidak diawali informasi nonimperatif di depannya.

Ketiga, intonasi tuturan dan isyarat-isyarat kinesik. Intonasi dibedakan menjadi dua, yakni: pertama, Intonasi yang menandai berakhirnya suatu kalimat atau intonasi final, dan kedua, Intonasi yang berada di tengah kalimat atau intonasi nonfinal. Fungsi dari intonasi ialah untuk memperjelas dan mempertegas tuturan. Berdasarkan intonasi dan isyarat-isyarat kinesik, yakni (a) volume; (b) ekspresi wajah; (c) sikap tubuh; (d) gerakan jari-jemari; (e) ayunan lengan; (f) gerakan lengan; (g) gerakan pundak; (h) goyangan pinggul; dan (i) gelengan kepala.

Keempat, ungkapan-ungkapan penanda kesantunan. Kesantunan pemakaian tuturan imperatif juga ditentukan oleh adanya ungkapan-ungkapan penanda kesantunan. Ungkapanungkapan penanda kesantunan tersebut, yakni: mohon, tolong, mari, jangan, silakan, ayo, coba, hendaklah, dan harap.

\section{Wujud Kesantunan Imperatif dan Makna Dasar Pragmatik Imperatif dalam Tuturan Antarmahasiswa}

Sebagaimana telah disebutkan di muka, fokus artikel ini tentang kesantunan imperatif dalam interaksi antarmahasiswa Melayu Sambas di FTIK IAIN Pontianak, atau secara khusus ingin memotret wujud kesantunan imperatif antar mahasiswa Melayu Sambas di FTIK IAIN Pontianak serta mendalami makna dasar pragmatik 
imperatif dalam interaksi antar mahasiswa Melayu Sambas di FTIK IAIN Pontianak ditinjau dari tingkat ilmu dan status kelembagaan.

\section{Wujud Kesantunan Imperatif}

Wujud formal imperatif dapat dibagi menjadi imperatif aktif dan imperatif pasif. Imperatif aktif dibagi menjadi dua yakni imperatif aktif berciri tidak transitif dan imperatif aktif berciri transitif dan imperatif aktif tidak transitif adalah kalimat yang tak berobjek. Penggunaan imperatif aktif berciri tidak transitif dalam interaksi antarmahasiswa FTIK IAIN Pontianak. Penggunaan imperatif aktif dapat dilihatpada contoh di bawah ini.

\section{Kaumaiy kæ rumahku beso?!}

'Kamu main ke rumahku besok!'

'Bermainlah ke rumahku besok!'

Sementara itu yang dimaksud dengan wujud imperatif pasif adalah realisasi terhadap bentuk imperatif yang verbanya pasif. Berikut ini terdapat bentuk-bentuk imperatif yang verbalnya pasif.

Min, bawaPlah tambol iye untukkan biak.

'Min, bawalah jajan ini buat teman-temanmu'

'Min, bawa jajan ini ke teman-temanmu'

Tuturan pada contoh-contoh di atas menunjukkan bahwa subjek imperatif di sini cenderung definitif. Hal ini dapat dibuktikan bahwa bentuk-bentuk tersebut cenderung tidak berterima.

\section{Makna Dasar Pragmatik Imperatif}

Hal-hal yang dimungkinkan mempengaruhi jenis makna pragmatik imperatif, antara lain secara umum adalah faktor kedudukan atau status sosial penutur (01) dan mitra tutur (02) dalam suatu peristiwa tutur. Perbedaan status sosial tersebut berlaku pada perbedaan tingkat ilmu (mahasiswa dan dosen) dan status kelembagaan (mahasiswa dan pejabat/pengurus kampus). Pada perbedaan tingkat ilmu bisa dilihat bagaimana interaksi mahasiswa terhadap mahasiswa, mahasiswa terhadap dosen atau sebaliknya, dan dosen terhadap dosen. Sedangkan pada status kelembagaan terlihat pada interaksi mahasiswa terhadap 
mahasiswa, mahasiswa terhadap pengurus atau staf atau sebaliknya, dan pengurus terhadap pengurus.

Selain itu, tuturan perintah atau imperatif yang telah diucapkan oleh penutur akan mengakibatkan beban bagi mitra tutur untuk melakukan suatu tindakan. Seberapa jauh 02 dapat menghindar dari beban itu atau seberapa jauh 02 boleh memilih melakukan atau tidak dari tindakan itu, juga siapa yang mendapat manfaat atau faedah dari terjadinya tuturan imperatif itu. Berdasarkan hal-hal ini maka kemungkinan bisa diketahui apa jenis makna dasar pragmatik imperatif dari ketujuh makna imperatif yang telah dikemukakan sebelumnya.

Kedudukan 01 terhadap 02 ini menurut penulis juga menentukan jenis makna dari tuturan pragmatik imperatif. Satu tuturan imperatif yang diucapkan oleh 01 dengan kedudukan 01 dan 02 sama akan berbeda jenis makna pragmatik imperatifnya bila diucapkan oleh 01 yang kedudukannya lebih rendah atau yang lebih tinggi daripada 02.

Sambil berkipas-kipas sebagai tanda kepanasan, seorang dosen sedang berbincang-bincang dengan dosen dan mahasiswa lainnya dalam suatu ruangan ketika sedang mengobrol bersama-sama. Seorang dosen tersebut menggunakan kalimat yang mengandung makna imperatif untuk membukakan pintu ruangan dengan menggunakan tuturan pada kalimat (1) berikut.

\section{Ruang itok panas lalu bæh.}

'Ruangan ini panas sekali'

Jika dilihat lebih teliti, maka satu tuturan pragmatik imperatif ini mengandung jenis makna lebih dari satu bila tanpa melihat ketiga jenis hubungan kedudukan 01 dan 02 di atas. Hal ini dapat dibuktikan dengan mengubah tuturan tersebut menjadi parafrase seperti di bawah ini.

Saya menyuruhmu untuk membuka jendela karena ruangannya panas sekali.

Saya memintamu untuk membuka jendela karena ruangannya panas sekali.

Kalimat (1) yang mengandung makna suruhan dimungkinkan dituturkan oleh 01 yang mempunyai kedudukan lebih tinggi daripada 02, yaitu dosen terhadap mahasiswanya. Kalimat (2) yang mempunyai makna permintaan dimungkinkan dituturkan oleh 01 yang mempunyai kedudukan sama dengan 02, 
yaitu teman sesama dosen dalam ruangan itu. Jika tuturan tersebut diucapkan dalam konteks antara dosen dan mahasiswadi kampus, makna yang dimungkinkan timbul bisa juga bermakna permohonan dengan dibuat parafrase Saya memohon pada anda untuk membuka jendela karena ruangannya panas sekali. Kalimat yang bermakna permohonan tersebut dimungkinkan dituturkan oleh 01 yang mempunyai kedudukan lebih rendah daripada 02. Namun tidak demikian untuk lingkungan kampus. Seorang mahasiswa dinilai tidak santun jika memerintah dosennya, meskipun makna yang terkandung dalam tuturan tersebut bermakna permohonan sekalipun. Hampir bisa dipastikan hal itu tidak pernah terjadi di kampus, meskipun jika tuturan tersebut merupakan tuturan tak.

Pada makna perintah, jika hasil tindakan berfaedah (menguntungkan) bagi 01 maka akan menjadi beban (kerugian) bagi 02, dan jika berfaedah bagi 02 kadang-kadang juga menjadi beban bagi 01. Tetapi dalam makna ini 02 dituntut harus melakukan suatu tindakan. Dengan kata lain faktor pilihan (option) 02 sangat kecil bahkan tidak ada. Perhatikan contoh berikut:

Pantau buku?uy! Sodah na'yeracau sorang.

'Dilihat bukunya! Jangan ngomong sendiri.'

'Lihat buku! Kalian jangan ngomong sendiri.'

Konteks tuturan:

Tuturan tersebut diucapkan dosen kepada mahasiswa ketika sedang mengajar dan mendapati mahasiswanya yang sedang bicara dengan temannya.

Pada makna permintaan, hasil dan tindakan 02 berfaedah (menguntungkan) bagi 01 (atau mungkin orang ketiga), dan sebaliknya menjadi beban (merugikan) bagi 02. Pilihan manasuka (option) untuk tidak melakukan atau melakukan suatu tindakan bagi 02 adalah "sedikit banyak ada". Perhatikan contoh berikut.

\section{Tuloy amberkan makalahku yang merah i!}

'Tolong, ambilkan makalahkumerah itu!'

'Tolong, ambilkan makalahku warna merah itu!'

Konteks tuturan: 
Tuturan di atas diucapkan mahasiswa kepada temannya di ruang kelas yang meminta tolong mengambilkan makalahnya yang berwarna merah.

Pada makna nasehat, hasil dari tindakan 02 berfaedah bagi 02 sendiri. Bagi 01 kadang-kadang tidak menjadi beban, tetapi kadang-kadang juga menjadi beban. Dalam makna ini pilihan manasuka (option) untuk tidak melakukan sesuatu atau melakukan suatu tindakan bagi 02 adalah "ada".

\section{Pakailah jam mun ujian}

'Pakailah jam kalau ujian.'

'Kalau ujian pakailah jam tangan.'

Konteks tuturan:

Tuturan tersebut terjadi antarmahasiswa ketika akan ujian tengah semester.

Hal penting yang perlu diperhatikan juga adalah bahwa masing-masing makna di atas tidak berdiri sendiri secara sempurna, misalnya pada makna permintaan dapat berubah menjadi makna perintah jika faktor option 02 untuk memilih tidak melakukan tindakan adalah tidak ada. Hal ini juga mengimplikasikan bahwa suatu jenis makna pragmatik imperatif dapat berubah seiring dengan peringkat untung-rugi 01 dan 02 serta peringkat option 02 , dan perubahan peringkat pada skala pragmatik ini dipengaruhi oleh hubungan atasan/bawahan antara 01 dan 02 seperti telah dijelaskan di atas.

Berdasarkan tiga makna dasar ungkapan yang menuntut tingkah laku mitra tutur seperti yang telah dijelaskan di atas, peneliti berusaha menentukan makna dasar atau makna pokok dari ketujuh makna imperatif dalam interaksi antarmahasiswa.Dalam penentuan tiga makna dasar ungkapan yang menuntut tingkah laku mitra tutur, penulis menggunakan skala untung-rugi dan skala option pada tuturan langsung (bentuk formal imperatif). Sedangkan skala kelangsungan tidak digunakan karena rumusannya sudah jelas digunakan untuk menentukan tingkat kesantunan tuturan imperatif, semakin suatu tuturan imperatif itu bersifat tidak langsung maka semakin santun pula tuturan itu. 


\section{Kajian Etis Pendidikan Islam terhadap Kesantunan Imperatif dalam Interaksi Antarmahasiswa FTIK IAIN Pontianak}

Kemampuan bertutur atau berbicara hakikatnya merupakan salah satu potensi bawaan (fithrah) yang diberikan Allah SWT pada manusia. Dengan kemampuan bertutur tersebut itulah, seseorang bisa membangun hubungan sosialnya. Kemampuan bertutur yang juga berhubungan dengan kemampuan berbahasa, akan dapat meningkatkan derajat seseorang. Bila seseorang mampu bertutur dengan santun, meyakinkan, menyenangkan, menarik dan beretika, maka derajatnya juga akan meningkat. Dalam kajian etis pendidikan Islam, kesantunan bertutur sesuatu hal yang sangat penting, dikarenakan ajaran Islam amat menekankan kesantunan dalam hal apapun. Dalam Al-Qur'an, ucapan yang baik lebih baik daripada sedekah yang diiringi sesuatu yang menyakiti hati si penerima. ${ }^{185}$

Berdasarkan hasil penelitian yang peneliti lakukan, banyak mahasiswa yang kurang santun dalam bertutur. Dalam temuan peneliti di lapangan, kesantunan mahasiswa dalam mengungkapkan perintah, keharusan atau melarang temannya melakukan sesuatu cenderung kurang sopan, yang tampak dari perilaku verbal dan non verbal tuturan imperatifnya. Padahal Bahasa tutur yang mereka gunakan seyogyanya adalah gambaran kepribadian mereka, dan menjadi problematik karena mereka kuliah di FTIK IAIN Pontianak yang memang disiapkan menjadi calon-calon guru. Sebagaimana dimafhumi, terdapat empat Program Studi saat ini di FTIK IAIN Pontianak, yaitu Pendidikan Agama Islam (PAI), Pendidikan Bahasa Arab (PBA), Pendidikan Guru Madrasah Ibtidaiyah (PGMI) dan Pendidikan Islam Anak Usia Dini (PIAUD).

Salah satu penyebabnya adalah karena faktor lingkungan asal, termasuk hal yang amat mempengaruhi Bahasa dan cara mereka bertutur. Sebab yang lain, karena belum ada aturan yang tertuang dalam kode etik mahasiswa yang mengatur tentang kesantunan bertutur di IAIN Pontianak, termasuk di Fakultas Tarbiyah dan Ilmu

185 Lihat: QS. Al-Baqarah [02] ayat 263. 
Keguruan. Etika mahasiswa dalam kode etik mahasiswa masih dijabarkan dalam penjelasannya yang umum.

Seharusnya, mahasiswa di FTIK IAIN Pontianak sebagai masyarakat kampus menyadari keberadaannya sebagai bagian tipologi komunitas masyarakat hard shelled, di mana pada komunitas ini terjadi interaksi minimal dan pemeliharaan maksimal pada Bahasa dan budaya. Pada aras ini, mahasiswa sudah sepatutnya menjaga keselarasan hubungan dengan sebisa mungkin dilandasi oleh kesantunan berbahasa. Sebab itu, kesantunan dalam bertutur, termasuk dalam mengungkapkan perintah, keharusan atau melarang temannya dilakukan secara santun.

Dalam kajian etis pendidikan Islam, kesantunan imperatif berhubungan erat dengan akhlaq bertutur, yang menjadi perhatian penting sumber-sumber ajaran Islam, baik dari Al-Qur'an, Hadits maupun pandangan ulama. Dalam QS. Al-Ahzab ayat 70-71, Allah SWT berfirman:

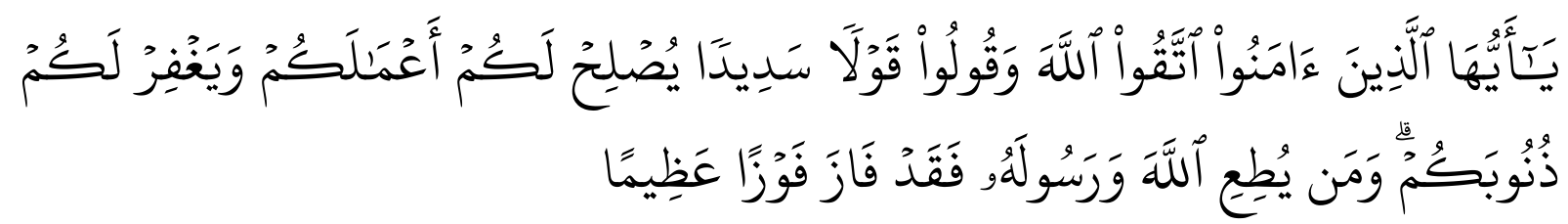

Artinya: "Hai orang-orang yang beriman, bertaqwalah kamu sekalian kepada Allah dan bertuturlah (dengan perkataan yang) benar, niscaya Allah memperbaiki amalan-amalanmu dan mengampuni dosa-dosamu. Barangsiapa yang menaati Allah dan Rasul-Nya, maka sesungguhnya dia telah memperoleh kemenangan yang besar." (QS. Al-Ahzab: 70-71)

Dalam ayat lain, yaitu pada QS. Qaf ayat 16-18, Allah SWT Berfirman:

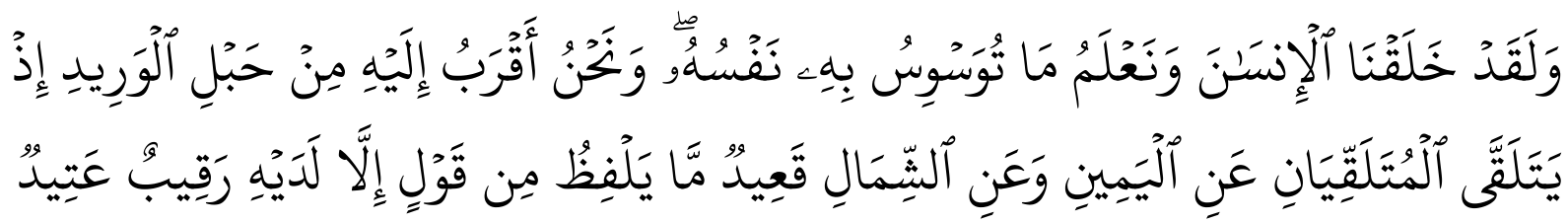

Artinya: "Dan sesungguhnya Kami telah menciptakan manusia dan mengetahui apa yang dibisikkan oleh hatinya, dan kami lebih dekat kepadanya dari urat lehernya, (yaitu) ketika dua orang malaikat mencatat amal perbuatannya, seorang duduk di sebelah kanan dan yang lain duduk di sebelah kiri. Tiada sesuatu perkataan yang dituturkannya, melainkan di dekatnya malaikat pengawas yang selalu hadir." (QS. Qaf: 16-18)

Diriwayatkan dalam sebuh hadits dari Abdullah bin Umar ra., bahwa Nabi Muhammad SAW., bersabda: "Seorang muslim adalah seseorang yang orang muslim lainnya selamat dari gangguan lisan dan tangannya." (HR. Bukhari, Nomor 10) Dalam riwayat lain dari Abu Hurairah, bahwa Nabi Muhammad Saw bersabda, 
"Barangsiapa yang beriman kepada Allah dan hari akhir, maka hendaklah dia bertutur yang baik atau diam." (HR Bukhari, Nomor 6475; HR Muslim, Nomor 74).

Dalam Syarhul Arba'iina Haditsan an-Nawawiyah, Ibnu Daqiqil ‘Ied menjelaskan maksud hadits, "Barangsiapa yang beriman kepada Allah dan hari akhir, maka hendaklah dia bertutur yang baik atau diam," maksudnya bahwa seorang muslim meti menjaga lisannya sehingga bertutur baik atau memilih diam dalam artian menahan diri (dari bertutur yang tidak baik).

Kesantunan imperatif hendaknya menjadi sebuah hal penting untuk dimiliki oleh mahasiswa FTIK IAIN Pontianak mengingat ini merupakan bagian dari kesadaran etis mereka sebagai calon guru. Asumsinya, seorang mahasiswa FTIK IAIN Pontianak, yang melekat dalam status mereka sebagai muslim, yang sepatutnya mempunyai kesantunan dalam hal apapun, dan hal ini dianggap amat penting dalam akhlaq atau etika Islam. Tidak berlebihan bila dikatakan bahwa ajaran agama tentang kesantunan dalam bertutur ini sebagai bagian yang tidak bisa dipisahkan dari pendidikan Islam sehingga mahasiswa FTIK IAIN Pontianak mesti terkondisikan untuk santun.

\section{E. Kesimpulan}

Kesantunan imperatif merupakan salah satu yang menjadi perhatian dalam pendidikan karakter. Hal ini karena kesantunan berbahasa atau bertutur menjadi bagian dari pilar pendidikan karakter. Hanya saja kesantunan imperatif ini seringkali hal ini luput dari perhatian lembaga pendidikan, termasuk pada perguruan tinggi keagamaan Islam. Berdasarkan penelitian yang peneliti lakukan, mahasiswa yang studi di FTIK IAIN Pontianak menunjukkan kecenderungan kurang santun dalam berbahasa atau bertutur, yang peneliti amati dari tuturan imperatif yang mereka gunakan.

Dalam temuan peneliti di lapangan, kesantunan mahasiswa dalam mengungkapkan perintah, keharusan atau melarang temannya melakukan sesuatu cenderung kurang sopan, yang tampak dari perilaku verbal dan non verbal tuturan imperatifnya. Padahal Bahasa tutur yang mereka gunakan seyogyanya adalah gambaran kepribadian mereka, dan menjadi problematik karena mereka kuliah di FTIK IAIN Pontianak yang memang disiapkan menjadi calon-calon guru. 
Sebagaimana dimafhumi, terdapat empat Program Studi saat ini di FTIK IAIN Pontianak, yaitu Pendidikan Agama Islam (PAI), Pendidikan Bahasa Arab (PBA), Pendidikan Guru Madrasah Ibtidaiyah (PGMI) dan Pendidikan Islam Anak Usia Dini (PIAUD).

Seharusnya, mahasiswa di FTIK IAIN Pontianak sebagai masyarakat kampus menyadari keberadaannya sebagai bagian tipologi komunitas masyarakat hard shelled, di mana pada komunitas ini terjadi interaksi minimal dan pemeliharaan maksimal pada Bahasa dan budaya. Pada aras ini, mahasiswa sudah sepatutnya menjaga keselarasan hubungan dengan sebisa mungkin dilandasi oleh kesantunan berbahasa. Sebab itu, kesantunan dalam bertutur, termasuk dalam mengungkapkan perintah, keharusan atau melarang temannya dilakukan secara santun.

Kesantunan imperatif sebagai bagian dari akhlaq bertutur dalam ajaran Islam, sepatutnya menjadi hal yang diperhatikan dalam pendidikan Islam. Hal ini sejalan dengan arah tujuan pendidikan Islam yang menghendaki manusia yang bermoral baik dan santun baik dalam bertutur maupun berbuat. Secara etis, pendidikan Islam memang perlu mengkondisikan keadaan (situasi dan kondisi belajar), materi pelajaran, dan sarana pembelajaran yang mendukung tujuan tersebut yang mendukung terbangunnya kesantunan pada peserta didik. Hal ini penting diperhatikan oleh lembaga-lembaga pendidikan Islam pada semua levelnya, termasuk FTIK IAIN Pontianak yang notabene merupakan bagian dari Perguruan Tinggi Keagamaan Islam.

\section{DAFTAR PUSTAKA}

Adelina, Yeti Prastika, "Kesantunan Imperatif dalam Wacana Pertemuan Kedinasan PCNA Sukolilo Kabupaten Pati," Skripsi tidak diterbitkan, Universitas Muhammadiyah Surakarta, 2013.

Amin, Ahmad, Etika (Ilmu Akhlaq), Jakarta: Bulan Bintang, 1975.

Chaer, Abdul, Kesantunan Berbahasa, Jakarta: Rineka Cipta, 2010. 
Djajasudarma, Fatimah, Metode Linguistik Rancangan Metode Penelitian dan Kajian, Bandung: Refika Aditama, 1993.

Ekopriyono, Adi, The Spirit of Pluralism: Menggali Nilai-nilai Kehidupan, Mencapai Kehidupan, Jakarta: Elex Media Komputindo, 2005.

Esti Nugraheni, Retno, "Wujud Pragmatik Kesantunan Imperatif dalam Proses Pembelajaran Siswa Kelas VIII SMP Negeri 1 Pondok Kelapa Bengkulu Tengah", dalam Jurnal Diksa, Vol. 2 No. 1 2016. (DOI: http:/ / ejournal.unib.ac.id/index.php/diksa)

Ibrahim, Abdul Syukur, Kajian Tindak Tutur, Surabaya: Usaha Nasional, 1992.

Rahardi, Kunjana, Pragmatik: Kesantunan Imperatif Bahasa Indonesia, Jakarta: Erlangga, 2005.

Rohali, "Kesantunan Berbahasa Sebagai Pilar Pendidikan Karakter: Perspektif Sosio Pragmatik", dalam Jurnal Pendidikan Karakter, Vol. 1, No. 1, 2011. (DOI:https:/ /journal.uny.ac.id/index.php/jpka)

Roni, “Jenis Makna Dasar Pragmatik-Imperatif dalam Bahasa Indonesia”, dalam Jurnal Verba, 2005.

Sauri, S., Meretas Pendidikan Nilai (Ed. 1), Bandung: Arfino Raya, 2010.

Undang-Undang Republik Indonesia nomor 20 tahun 2003 tentang Sistem Pendidikan Nasional, Jakarta: Departemen Pendidikan Nasional Republik Indonesia, 2004. 